\title{
Global Citizenship Education in South Korea through Civil Society Organizations: Its Status and Limitations*
}

\author{
Sim, HeeJung Raina**
}

\section{Abstract}

This study aims to analyze global citizenship education (GCED) content programming offered by civil society organizations (CSOs) in South Korea. Drawing from Andreotti's (2006) two strands of proposed concept on GCED, the paper identifies the current status and limitations of the GCED programs offered in Korea; thus, draws recommendation for the future GCED program development. The study finds that many GCED programs are heavily focused on humanistic towards a justice-oriented perspective or 'soft' approach rather than balancing the fundamental structures that enable learners to recognize global power imbalances, or critical approach. The study argues that providing a well balanced program that integrates two strands of GCED is imperative as CSOs to play a key role through non-formal and informal education that complements formal education's provision. The study thus suggests that a complex web of cultural and material local/global contexts needs to be examined during the GCED program design in order to further foster 'critical' practice of GCED that was identified by Andreotti.

Key words: global citizenship education, civil society organization, critical global citizenship

* This study was supported by the Asia Development Institute of Graduate School of Public Administration at Seoul National University.

** Postdoctoral Fellow, Asia Development Institute, Seoul National University. 


\section{I . Introduction}

There has been an exponential growth in the interest in global citizenship education (GCED) over the past decade, and South Korea is no exception. As the United Nation's Secretary-General Ban Ki-Moon introduced 'fostering global citizenship' as one of his key priorities in the Global Education First Initiative (GEFI) in 2012, the South Korean government eagerly support GCED as a part of the new national education initiatives. In a bid to promote GCED as a part of nation's education agenda, the government puts forth its efforts to lobby for GCED to be at the heart of Sustainable Development Goals (SDGs) targets, promoting quality education for all (Chung, 2014; Ministry of Foreign Affairs of the Republic of Korea, 2013). Nevertheless, such has been no more than peripheral of recommendation and it seems that GCED remained a low priority for implementation at the educational institutional level; therefore, the absence of curricular offerings through schools have been shifted to civil society organizations $\left.(\mathrm{CSOs})^{1}\right)$ where it had reinforced the education delivery roles in place of traditional classrooms. From 2005 to 2015, the number of GCED programs offered by CSOs in South Korea has increased threefold (Sim \& Kim, 2015). Currently, there are approximately thirty CSOs offering GCED program in Korea, and the numbers continue to escalate to date. Despite this movement, limited studies have been reported on the evaluating of Korean CSOs roles, practice and commitments in GCED.

This study classifies the GCED programs offered in Korea using Andreoitti's (2006) two strands - soft and critical GCED - to provide insights into the CSOs' GCED programming practices and status. This study therefore aims to critically analyze the current status and limitations of Korean CSOs work in GCED through explanatory research with the use of qualitative document analysis. Due to the scarcity of literature and adequate research on this particular topic, the study mainly resorts to the 2015 Korea Civil Society Forum on International Development Cooperation's (KOFID) technical report on GCED (KOFID, 2015), and other available related research (Han, Lee \& Shin, 2012; KCOC, 2014; Kim et al., 2014; Lee, 2009; Sung, Lee \& Kim, 2014). Relevant resources from regional reports, websites and

1) The study has chosen to use the term civil society organizations or CSOs since the phrase non-government organization or NGO is contested terminology and many has been subsumed within a broad category of CSOs. In this study, CSOs are defined as voluntary organizations with governance and direction coming from citizens or constituency members, without significant government-controlled participation or representation. 
news materials have been reviewed in order to make broader arguments about the GCED program investigation. While interview-based research with practitioners and students of these CSOs would have been valuable to understand the intrinsic value of the individual understanding of GCED, analysis of the programs as well as the timing and limited duration of the research period precluded interviews. Similarly, it would have been ideal and valuable to observe these programs for in-depth analysis. However, the timing of the research and available programs offerings did not allow the opportunity to do so.

Nevertheless, it is strongly believed that there is still a value in examining the programs critically the way in which these CSO's GCED programs are opearated and managed through their own promotional materials and available reports conducted through third party agencies. Thus, the study broadly argues about the programs per se to analyze GCED programs. Furthermore, since the theoretical meaning of GCED is yet to be agreed upon and continues to be contested among scholars, the next section attempts to depict the meaning of GCED in order to provide a background understanding for this study.

\section{Conceptual Framework of Global Citizenship Education}

\section{Definition and Concepts of Global Citizenship Education}

To date, many competing definitions and concepts of GCED have been proposed and have emerged across the literature and practices. The concepts of GCED have been borrowed, re-used, re-visioned, and formulated into "new" definitions that have similar theoretical constructs and practices as "old" definitions. Proponent of human rights education, environmental education, sustainable development education, world studies, development education and global education found common ground in the growing acceptance of GCED (Standish, 2008). Thus, formulating a consensus on GCED through comparative literature seem to be inconsistent and challenging due to differences of its theoretical standpoints or assumptions. The following table (Table 1) summarizes pertinent concept of GCED proposed by established international organizations, civil society organizations, academics and research institutions. 
$<$ Table 1> Outlines of Proposed Concept of GCED

\begin{tabular}{|c|c|}
\hline Author & Concept \\
\hline $\begin{array}{l}\text { Davies, } \\
\text { Evans, \& } \\
\text { Reid (2005) }\end{array}$ & $\begin{array}{l}\text { - Grown out of the practice of global education, [GCED] focuses on } \\
\text { international awareness through participatory learning and by engaging } \\
\text { in holistic learning activities (p.6). }\end{array}$ \\
\hline $\begin{array}{l}\text { O' Sullivan } \\
\text { \& Pashby } \\
\text { (2008) }\end{array}$ & $\begin{array}{l}\text { - GCED encourages students to understand globalization, to adopt } \\
\text { self-critical approach to how they and their nation are implicated in } \\
\text { local and global problems, to engage in intercultural perspectives and } \\
\text { diversity, and to recognize and use their political agency towards } \\
\text { effecting change and promoting social and environment justice (p.17). }\end{array}$ \\
\hline Pak (2013) & $\begin{array}{l}\text { - GCED is education that empowers learners to engage and assume } \\
\text { active role both locally and globally to face and resolve global } \\
\text { challenges and ultimately to become proactive contributors to a more } \\
\text { just, peaceful, tolerant, inclusive, secure and sustainable world (p.34). } \\
\text { - GCED provides a transformative experience, giving learners the } \\
\text { opportunity and competencies to consider their rights and obligations to } \\
\text { promote a better world and future (p.34). }\end{array}$ \\
\hline
\end{tabular}

- Empowering learners to engage and assume active roles, both locally and globally: Education which aims to develop the knowledge, skills, values, and attitudes learners need for securing a world, which is more,

UNESCO just, peaceful, tolerant, inclusive, secure and sustainable;

(2013) - Conceived as a transformative learning process;

- Flexible and variable pedagogical approaches can be applied;

- Transdisciplinary field: It applies a multifaceted approach employing concepts, methodologies and theories from related fields.

- Education that helps enable young people to develop the core Oxfam (2006) competencies which allow them to actively engage with the world, and help to make it more just and sustainable place.

- GCED is a transformative learning process, which plays a pivot role in socialization of the future citizens whilst developing their value and attitude.

- GCED is an umbrella term covering themes such as life skills education, peace education, and human right education. Of particular, importance

Education

Above All

(2012) in many setting is acceptance of diversity, respect for the rights of others, and the development of collaboration skills to peacefully solve shared problem.

- GCED is education that prepares students to play an active role and positive role in their dealing with school, family, society and globally. This includes being active and responsible participants in their own community, and when possible being active and responsible participants in the wider community of human being, their own regions and on Planet Earth. 
While GCED concepts are still being debated and shaped, three common characteristics of GCED that characterize its core have been broadly agreed. First, GCED refers to raising awareness and understanding of the interdependence of problem distressing the planet; and, local actions have a global effect and vice versa. This makes people responsible for the future of mankind, and of the sustainable planet, within a concept of global citizenship that integrates the local and the global dimensions. Second, GCED enables learners to develop problem solving skills as well as critical thinking skills through finding local and global issues and identifying causal relationships from integrated perspectives. Lastly, GCED empowers learners to engage and assume active roles; hence, focusing on engagement in individual and collective action to bring about desired changes.

As defined in many ways by different schools of thoughts, taking the meaning of each word literally, the meaning and value of global citizenship can be interpreted as how one may discover and embrace different aspect of our world to become a better and more worldly citizen. In this retrospect, the principles and concepts of GCED in this study can be summarized as: 'education that empowers students to engage and assume proactive roles, in order to face and resolve global issues and challenges therefore, ultimately to become a citizenry agent for a more just, peaceful, tolerant, inclusive, secure and sustainable world.'

\section{Andreotti's Strands of Global Citizenship Education}

To understand the trend of current GCED programs offered by the Korean CSOs, it calls for the need of GCED analytical content framework. Using Dobson and Spivak's analysis, Andreotti (2006) proposes a framework for GCED categorical content analysis, which consists of two strands of concepts in GCED, soft and critical learning. Table 2 summarizes the comparison between soft and critical GCED.

<Table 2> Andreotti's Framework for GCED : Soft verses Critical

\begin{tabular}{|c|c|c|}
\hline & Soft Global Citizenship Education & Critical Global Citizenship Education \\
\hline Problem & - Poverty, helplessness & - Inequalities, injustice \\
\hline $\begin{array}{c}\text { Nature of the } \\
\text { problem }\end{array}$ & $\begin{array}{l}\text { - Lack of 'development', } \\
\text { education, resources, skills, } \\
\text { culture, technology, etc. }\end{array}$ & $\begin{array}{l}\text { Complex structures, systems, } \\
\text { assumptions, power relations and } \\
\text { attitudes that create and maintain } \\
\text { exploitation and enforced } \\
\text { disempowerment and tend to } \\
\text { eliminate difference. }\end{array}$ \\
\hline
\end{tabular}




\begin{tabular}{|c|c|c|}
\hline $\begin{array}{l}\text { Justification for } \\
\text { position of } \\
\text { privilege (in the } \\
\text { North and in } \\
\text { the South) }\end{array}$ & $\begin{array}{l}\text { - 'Development', 'history', } \\
\text { education, harder work, } \\
\text { better organization, better use } \\
\text { of resources, technology. }\end{array}$ & $\begin{array}{l}\text { Benefit from and control over } \\
\text { unjust and violent system and } \\
\text { structure. }\end{array}$ \\
\hline Basis for caring & $\begin{array}{l}\text { Common humanity/being } \\
\text { good/ sharing and caring. } \\
\text { Responsibility and caring. } \\
\text { Responsibility FOR the other } \\
\text { (or to teach the other) }\end{array}$ & $\begin{array}{l}\text { - Justice/complicity in harm. } \\
\text { Responsibility TOWARDS the } \\
\text { other (or to learn with the other) } \\
\text { - accountability. }\end{array}$ \\
\hline $\begin{array}{l}\text { Grounds for } \\
\text { acting }\end{array}$ & $\begin{array}{l}\text { Humanitarian/moral (based } \\
\text { on normative principles for } \\
\text { thought and action). }\end{array}$ & $\begin{array}{l}\text { Political/ethical (based on } \\
\text { normative principles for } \\
\text { relationships). }\end{array}$ \\
\hline $\begin{array}{l}\text { Understanding } \\
\quad \text { of } \\
\text { interdependence }\end{array}$ & $\begin{array}{l}\text { - We are all equally } \\
\text { interconnected, we all want } \\
\text { the same thing, we can all } \\
\text { do the same thing. }\end{array}$ & $\begin{array}{l}\text { Asymmetrical globalization, } \\
\text { unequal power relations, } \\
\text { Northern and Southern elites } \\
\text { imposing own assumptions as } \\
\text { universal. }\end{array}$ \\
\hline $\begin{array}{c}\text { What needs to } \\
\text { change }\end{array}$ & $\begin{array}{l}\text { - Structures, institutions and } \\
\text { individuals that are a barrier } \\
\text { to development. }\end{array}$ & $\begin{array}{l}\text { Structures, systems, institutions, } \\
\text { assumptions, cultures, individuals, } \\
\text { relationships. }\end{array}$ \\
\hline What for & $\begin{array}{l}\text { So that everyone achieves } \\
\text { development, harmony, } \\
\text { tolerance and equality. }\end{array}$ & $\begin{array}{l}\text { So that injustices are addressed, } \\
\text { more equal grounds for dialogue } \\
\text { are created, and people can have } \\
\text { more autonomy to define their } \\
\text { own development. }\end{array}$ \\
\hline $\begin{array}{l}\text { What } \\
\text { individuals can } \\
\text { do }\end{array}$ & $\begin{array}{l}\text { - Support campaigns to change } \\
\text { structures, donate time, } \\
\text { expertise and resources. }\end{array}$ & $\begin{array}{l}\text { - Analyze own position/context } \\
\text { and participate in changing } \\
\text { structures, assumptions, identities, } \\
\text { attitudes and power relations in } \\
\text { their contexts. }\end{array}$ \\
\hline $\begin{array}{l}\text { How does } \\
\text { change happen }\end{array}$ & $\begin{array}{l}\text { - From the outside to the } \\
\text { inside (imposed change) }\end{array}$ & $\begin{array}{l}\text { - From the inside to the outside } \\
\text { (negotiated change) }\end{array}$ \\
\hline $\begin{array}{l}\text { Goal of global } \\
\text { citizenship } \\
\text { education }\end{array}$ & $\begin{array}{l}\text { Empower individuals to act } \\
\text { (or become active citizens) } \\
\text { according to what has been } \\
\text { defined for them as a good } \\
\text { life or ideal world. }\end{array}$ & $\begin{array}{l}\text { Empower individuals: to reflect } \\
\text { critically on the legacies and } \\
\text { processes of their cultures and } \\
\text { contexts, to imagine different } \\
\text { features and to take } \\
\text { responsibility for their decisions } \\
\text { and actions. }\end{array}$ \\
\hline $\begin{array}{l}\text { Potential } \\
\text { benefits of } \\
\text { global } \\
\text { citizenship } \\
\text { education }\end{array}$ & $\begin{array}{l}\text { - Greater awareness of some } \\
\text { of the problems, support for } \\
\text { campaigns, greater motivation } \\
\text { to help/do something, feel } \\
\text { good factor. }\end{array}$ & $\begin{array}{l}\text { - Independent/critical thinking and } \\
\text { more informed, responsible and } \\
\text { ethical action. }\end{array}$ \\
\hline $\begin{array}{l}\text { Potential } \\
\text { problems. }\end{array}$ & $\begin{array}{l}\text { Feeling of self-importance and } \\
\text { self-righteousness and/or cultural } \\
\text { supremacy, reinforcement of } \\
\text { colonial assumptions and } \\
\text { relations, reinforcement of } \\
\text { privilege, partial alienation, } \\
\text { uncritical action. }\end{array}$ & $\begin{array}{l}\text { - Guilt, internal conflict and } \\
\text { paralysis, critical disengagement, } \\
\text { feeling of helplessness. }\end{array}$ \\
\hline
\end{tabular}

Note: Adopted from "Soft versus Critical Global Citizenship Education," by V. Andreotti, 2006, Canada. 
As illustrated in Table 2, distinctions between soft and critical GCED hinge on whether it goes beyond the humanistic towards a justice-oriented perspective and the recognition of complicity in harm. For instance, 'soft' GCED, according to Andreotti, is an approach that raises awareness and funding in order to combat the immediate sources of suffering in the developing world such as poverty, lack of resources and limited access to education. Andreotti (2006) cites the work of Dobson (2005), who makes a useful distinction between being a human being, which raises issues of morality, and being a citizen, which raises political issues. To Andreotti (2006), the goal of 'soft' global citizenship, influenced by cosmopolitan notions, is to "empower individuals to act (or become active citizens) according to what has been defined for them as a good life or ideal world" (p.48).

Contrastingly, 'critical' GCED is a method that focuses on the fundamental structures that produce poverty. In this retrospect, 'critical' GCED enables the learners to recognize global power imbalances; and this allows leaners to be able to raise their opinions and take appropriate actions towards bringing 'justice' to the world. For instance, critical GCED teaches learners that they are implicated in the power structures that have brought a pair of shoe into their hand for a good price, but at a high social cost to the export nation. By doing so, it allows learners to ask the power structures that lead to the disparity of others instead of simply putting money into fund to fix superficial issues. Andreotti continues to point out that critical does not imply "right or wrong, biased, true or false" (2006:49) but rather an attempts to "understand the origin of assumptions and implications" (49). While Andreotti acknowledges the necessity of 'soft' global citizenship education at the certain contexts and recognizes as a major step, she emphasizes that it should not "stop there" (Andreotti, 2006: 49). She warns:

If educators are not 'critically literate' to engage with assumptions and implications/limitation of their approaches, they run the risk of reproducing systems of belief and practices that harm those they want to support. The question of how far educators working with global citizenship education are prepared to do that in the present context in the North [developed world, as opposed to the South which represents developing world] is open to debate. (Andreotti, 2006, pp. 49-50)

Participating activities that simply promote charity services and volunteerism at community level, Andreotti stresses the need of educating the learners on understanding of interconnectedness and interdependency of global systemic formation through a more 
analytical studies of global structures and its historical backgrounds.

Based on a literature review, Oxfam UK is considered to be an example of GCED program that satisfies Andreotti's two strands (Blackmore, 2014; Martin, 2008; Massey, 2014). The global citizenship theme is the hallmark of UK's Oxfam curriculum, which it defines as (i) thinking critically about complex global issues, (ii) understanding how the world works, and (iii) being willing to take action to make the world a just and equitable place (Oxfam, 1997). For this, Oxfam puts forth active learning strategies that are placed on a continuum from minimal to maximal approach in order to challenge the values and attitudes of both students and teachers. The knowledge, skill and value structure inherent in their program consists of:

Knowledge and understanding: Social justice and equity, Peace and conflict, Diversity, Sustainable development, Globalization and interdependence.

Skills: Critical thinking, Ability to argue effectively, Ability to challenge injustice and inequalities, Respect for people and things, Cooperation and conflict resolution.

Values and attitudes; Sense of identity and self-esteem, Empathy, Commitment to social justice and equity, Value and respect for diversity, Concern for the environment and commitment to sustainable development, Belief that people can make a difference (Oxfam, 2006:4, as sited in Gadsby \& Bullivant, 2011, p. 69).

At the earlier stage, a typical Oxfam GCED program focus on providing learners with the knowledge of global issues, cultures, international system. This involves passive elements of learning GCED where it introduces the formation of and acquiring a sense of global identity and solidarity with others around the world. As their knowledge, skills, and attitudes advance, the program integrates approach that goes beyond learning about other people and other places. Here, critical thinking skills and related techniques are taught in depth where it includes listening skills and asking questions in the foundation years to engaging in critical analysis of information and complex and contentious issues in high school (Oxfam, 2006). The program specifies learners to develop critical thinking and effective communications skills through various learning tools such as debates, team works, and group discussions. These tools are used as a form of expressing a point of view at the elementary level and by high school as taking a part in political process; thus, influencing political decision making at 
various levels seem to be the key plank of GCED.

Although political literacy forms one of the key strands of citizenship education in England, this is not explicitly featured in the Oxfam guidance for promoting global citizenship. This may take the form of knowledge and understanding of how political system works as well as skills to participate and learning to influence changes through advocating for particular issues such as fair trade or free universal primary education (Gadsby \& Bullivant, 2011). Nevertheless, global issues consist of a complex web of socio-economic-cultural glocal process and intricately connected together. In this respect, without understanding and unpacking the complex structure and dynamics of globalization, it would be difficult to initiate the process of solving the issues. Such recognition of global interdependence and interconnectedness in the era of globalization has put greater demands on education for global citizenship (Falk, 1994; Nodding, 2005), which signalizes a shift in the role and purpose of education to that of forging more just, peaceful, tolerant, inclusive and sustainable societies.

\section{Global Citizenship Education Programming offered by CSOs in Korea}

\section{Overview}

As aforementioned, GCED as a body of educational practice has been increased by several folds during the past decade. In spite of its widespread interests, the funding priorities of systematic development of GCED was continuously being challenged. Thus, monetary support for GCED in Korea has largely depended on self-funding of local CSOs. However, as the government pushes to promote GCED at both national and international level, more and more CSOs began to depend on governments for their funding.

Since the launch of Global Civic Sharing Initiative in the early 2000s, more institutions have participated in the offerings of GCED-related programs. YMCA Korea, for instance, has transformed its Democratic Citizenship Education program into GCED to conform with the global education trends. World Vision, on the other hand, launched a GCED program to raise awareness of its development activities while providing training for their staff as a part of advocacy activities since 2007. Furthermore, other organizations have similarly shifted their 
previous programs for the development of GCED programs. Despite of different starting points, CSOs' GCED programings in Korea in general aim to enhance public understanding of international development cooperation issues while preparing citizens to participate in issues and challenges both in local and global society. The following table further provides a brief general description of CSOs offering GCED programs in South Korea.

$<$ Table 3> List of Civil Society Organizations Involved in GCED in South Korea

\begin{tabular}{|c|c|c|c|}
\hline Organizations & Name & Target & Program Content \\
\hline Go \& Do & $\begin{array}{l}\text { Planet } \\
\text { Citizenship } \\
\text { Education }\end{array}$ & $\begin{array}{ll}\text { - } & \text { Primary } \\
\text { - Secondary (Middle/High) } \\
\text { - Post-secondary and } \\
\text { Continuing Ed. } \\
\end{array}$ & $\begin{array}{l}\text { - Education } \\
\text { - Instructor training } \\
\text { - School teacher training }\end{array}$ \\
\hline $\begin{array}{l}\text { Educators } \\
\text { Without } \\
\text { Borders }\end{array}$ & $\begin{array}{l}\text { International } \\
\text { Development } \\
\text { Education }\end{array}$ & $\begin{array}{l}\text { Post-secondary and } \\
\text { Continuing Ed. }\end{array}$ & - School teacher training \\
\hline $\begin{array}{l}\text { Good } \\
\text { Neighbors }\end{array}$ & $\begin{array}{l}\text { Global } \\
\text { Citizenship } \\
\text { Education }\end{array}$ & $\begin{array}{l}\text { - Primary } \\
\text { - Secondary (Middle) }\end{array}$ & $\begin{array}{l}\text { - Curriculum development } \\
\text { - Camp } \\
\text { - Global Leadership Camp }\end{array}$ \\
\hline Good People & $\begin{array}{l}\text { Future } \\
\text { Citizenship } \\
\text { Education }\end{array}$ & - Secondary (Middle/High) & $\begin{array}{l}\text { - Youth group (Global } \\
\text { Leadership Program) }\end{array}$ \\
\hline $\begin{array}{l}\text { Korea Food } \\
\text { for the } \\
\text { Hungry } \\
\text { International }\end{array}$ & $\begin{array}{l}\text { Global } \\
\text { Citizenship } \\
\text { Education }\end{array}$ & $\begin{array}{l}\text { - } \text { Pre-K } \\
\text { - Primary } \\
\text { - Secondary (Middle/High) }\end{array}$ & $\begin{array}{l}\text { - Curriculum development } \\
\text { - Youth group } \\
\text { - On-site teaching }\end{array}$ \\
\hline Better world & $\begin{array}{c}\text { Global } \\
\text { Citizenship } \\
\text { Education }\end{array}$ & - Secondary (High) & $\begin{array}{l}\text { - Curriculum development } \\
\text { - Youth group }\end{array}$ \\
\hline Medipeace & $\begin{array}{c}\text { Development } \\
\text { Education }\end{array}$ & $\begin{array}{l}\text { - Post-secondary and } \\
\text { Continuing Ed. }\end{array}$ & $\begin{array}{ll}\text { - } & \text { Lecture } \\
\text { - } & \text { Mentoring } \\
\end{array}$ \\
\hline $\begin{array}{l}\text { Service for } \\
\text { Peace }\end{array}$ & $\begin{array}{c}\text { Global } \\
\text { Citizenship } \\
\text { Education } \\
\end{array}$ & - Secondary (Middle/High) & $\begin{array}{l}\text { - Speech competition } \\
\text { - Camp } \\
\text { - Conference }\end{array}$ \\
\hline World Vision & $\begin{array}{l}\text { Global } \\
\text { Citizenship } \\
\text { Education }\end{array}$ & $\begin{array}{ll}\text { - } & \text { Pre-K } \\
\text { - } & \text { Primary } \\
\text { - } & \text { Secondary (Middle/High) } \\
\text { - } & \text { Post-secondary and } \\
& \text { Continuing Ed. } \\
\end{array}$ & $\begin{array}{l}\text { - } \text { Curriculum development } \\
\text { - Instructor training } \\
\text { - School teacher training } \\
\text { - Youth group } \\
\text { - GCED center }\end{array}$ \\
\hline $\begin{array}{l}\text { World } \\
\text { Together }\end{array}$ & $\begin{array}{l}\text { Global } \\
\text { Citizenship } \\
\text { Education }\end{array}$ & $\begin{array}{l}\text { - } \text { Primary } \\
\text { - Secondary (Middle/High) } \\
\text { - Post-secondary and } \\
\text { Continuing Ed. }\end{array}$ & $\begin{array}{l}\text { - } \quad \text { Curriculum development } \\
\text { - Instructor training } \\
\text { - Intensive } \\
\text { seminar/workshops }\end{array}$ \\
\hline
\end{tabular}




\begin{tabular}{|c|c|c|c|}
\hline Organizations & Name & Target & Program Content \\
\hline $\begin{array}{l}\text { Global Civic } \\
\text { Sharing }\end{array}$ & $\begin{array}{l}\quad \text { Planet } \\
\text { Citizenship } \\
\text { Education }\end{array}$ & $\begin{array}{l}\text { - Secondary (Middle/High) } \\
\text { - Post-secondary and } \\
\text { Continuing Ed. }\end{array}$ & $\begin{array}{l}\text { - Camp } \\
\text { - Overseas volunteer } \\
\text { service }\end{array}$ \\
\hline Copion & $\begin{array}{l}\text { Planet } \\
\text { Citizenship } \\
\text { Education }\end{array}$ & $\begin{array}{ll}\text { - } & \text { Pre-K } \\
\text { - } & \text { Primary } \\
\text { - } & \text { Secondary (Middle/High) } \\
\text { - } & \text { Post-secondary and } \\
& \text { Continuing Ed. }\end{array}$ & $\begin{array}{l}\text { - Curriculum development } \\
\text { - Instructor training } \\
\text { - Camp } \\
\text { - Model United Nations }\end{array}$ \\
\hline $\begin{array}{l}\text { Team \& } \\
\text { Team }\end{array}$ & $\begin{array}{c}\text { International } \\
\text { Development } \\
\quad \& \\
\text { Cooperation } \\
\text { Education }\end{array}$ & $\begin{array}{l}\text { - Primary } \\
\text { - Secondary (Middle/High) } \\
\text { - Post-secondary and } \\
\text { Continuing Ed. }\end{array}$ & $\begin{array}{l}\text { - } \text { Curriculum development } \\
\text { - Instructor training } \\
\text { - School teacher training } \\
\text { - Camp } \\
\text { - Youth group (Youth } \\
\quad \text { Global Action) } \\
\end{array}$ \\
\hline Friend Asia & $\begin{array}{l}\text { Global } \\
\text { Leadership } \\
\text { Education }\end{array}$ & 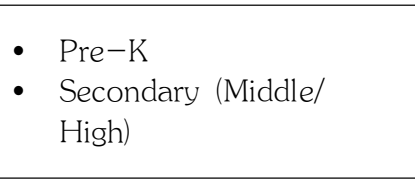 & $\begin{array}{l}\text { - Customized Lecture } \\
\text { Series (4 modules for } \\
\text { Pre-K; } 12 \text { modules for } \\
\text { Secondary) }\end{array}$ \\
\hline $\begin{array}{l}\text { Caritas } \\
\text { Korea }\end{array}$ & $\begin{array}{l}\text { Planet } \\
\text { Citizenship } \\
\text { Education }\end{array}$ & $\begin{array}{l}\text { - Secondary (Middle/High) } \\
\text { - Post-secondary and } \\
\text { Continuing Ed. }\end{array}$ & $\begin{array}{l}\text { - Customized Lecture } \\
\text { Series (4 modules for } \\
\text { Secondary) }\end{array}$ \\
\hline JTS Korea & $\begin{array}{l}\text { Global } \\
\text { Citizenship } \\
\text { Education }\end{array}$ & - Secondary (Middle/High) & - Youth workshop \\
\hline YMCA Korea & $\begin{array}{l}\text { Planet } \\
\text { Citizenship } \\
\text { Education }\end{array}$ & - Secondary (Middle/High) & - Camp \\
\hline $\begin{array}{l}\text { One Body } \\
\text { One Sprit }\end{array}$ & $\begin{array}{l}\text { Planet } \\
\text { Citizenship } \\
\text { Education }\end{array}$ & - Secondary (Middle/High) & $\begin{array}{ll}\text { - } & \text { Curriculum development } \\
\text { - Camp } \\
\text { - Youth group (Planet } \\
\text { Citizenship Supporters) }\end{array}$ \\
\hline $\mathrm{HoE}$ & $\begin{array}{l}\text { Global } \\
\text { Citizenship } \\
\text { Education }\end{array}$ & $\begin{array}{l}\text { - Secondary (Middle/High) } \\
\text { - Post-secondary and } \\
\text { Continuing Ed. }\end{array}$ & $\begin{array}{l}\text { - Curriculum development } \\
\text { - School teacher training } \\
\text { - Youth group (Teachers } \\
\text { Association) }\end{array}$ \\
\hline
\end{tabular}

Note: Adopted from "Issues and Implications of International Educational Development and Cooperation for the Korean Civil Society Organizations", by KOFID, 2015, Seoul.

As the KOFID report (2015) suggests, approximately 63\% of the current GCED program are currently implemented through in-school outreach programs, followed by GCED specific camp $(42 \%)$, youth group $(32 \%)$ and school teacher training (23\%). In-school outreach programs often consist of creative experiential learning activities, regular class, volunteer group, or other relevant clubs which take more than one semester. In terms of educational 
contexts or curriculum design, most organizations reported that they have either developed their own educational materials or adopted previous guidelines developed by the Korea NGO Council For Overseas Development Cooperation (KCOC). However, approximately 50\% of in-house developed curriculum are mainly made through simple translations of the overseas educational materials. Most programs accommodate a broad range of educational target groups from pre-K to adults and differentiate levels of curriculum upon request; yet, the source of the curriculum is not as segmented as the GCED programs in the UK or US. Meanwhile, the names of their programs vary from one organization to another due to their different roles and mission of GCED providers (e.g. future citizenship education, global citizenship/leadership education, international development education, planatery citizenship education). Nevertheless, they all aim to foster global citizenship with knowledge, skills, and value that are necessary to overcome global challenges and to live together.

Given the short history of the GCED provision attempts by CSOs in Korea, limited number of research on Korea's CSOs roles and mission, as well as outcomes are available. When reviewing the aforementioned programs, most have been limited with respect to actual educational content. Only few were found to be qualitatively analyzable. Thus, the study review those organizations based on available sources while employing Andreotti's strands of GCED, though other programs are referred from time to time. Considering the scope of study and available resources, it should be further noted that the study mainly focuses on secondary level since it is the most frequently targeted group (70\%).

\section{An Analysis of Exemplary GCED Programs}

\section{1) Major Players}

The size and reputations of organizations tend to have a positive relation to the marketability with diverse campaigns and programs. Nevertheless, they do not necessarily lead towards the balanced or so-called solely 'critical' approach to GCED. For instance, World Vision Korea, one of the largest Korean GCED CSO providers, estimated that the number of participants reached over three hundred thousands in 2013 (Kim et al. 2014). The purpose of their program is to help people to understand and recognize that everyone's life is interconnected and interweaved with each other under the umbrella of a global village (UNESCO APCEIU, 2013). This helps 
people to "better understand the impact and significance of issues taking place not only around them, but also in other parts of the world, thus gaining a comprehensive understanding of the intricate interconnectedness of global community" (UNESCO APCEIU, 2013:23). The program consists of five different activities: (1) global citizenship school, where students are trained to become global citizens to participate in addressing global issues in order to make a better world based on sense of responsibility, (2) global citizenship training center, where people get an opportunity to understand and sympathize with the underprivileged people in the world and think about ways to help them, (3) visiting schools, which often associates with the formal education system, (4) training school teachers, which trains school teachers, and (5) nurturing lecture. Among the five activities, global citizenship school and visiting schools have been most prolific due to the support of provincial offices of education. The primary topics include, but not limited to: human rights, environment, child/maternal health and peace; and, based on those topics, age-specific learning curriculum are further utilized for five course hours. Table 4 describes its specific learning themes and content for secondary level, as presented in World Vision (2016).

$<$ Table 4> Learning Content of World Vision's GCED Program: Focusing on Secondary Level

\begin{tabular}{|c|c|}
\hline Possible Topics & Learning Objectives and Contents \\
\hline Human Rights & $\begin{array}{l}\text { - What is human rights? } \\
\text { - Why is poverty a problem related to human rights? } \\
\text { - What are some of the cases of human rights violations? } \\
\text { - We are all equal and all valuable human beings. }\end{array}$ \\
\hline $\begin{array}{l}\text { Environment and } \\
\text { Poverty }\end{array}$ & $\begin{array}{l}\text { - Our precious Earth } \\
\text { - How the Earth is suffering from environmental destruction and } \\
\text { - how that suffering is related to our life? }\end{array}$ \\
\hline $\begin{array}{l}\text { Globalization and } \\
\text { Culture }\end{array}$ & $\begin{array}{l}\text { - Both profits and setbacks of globalization } \\
\text { - Respecting various races, societies and cultures }\end{array}$ \\
\hline $\begin{array}{l}\text { Child Health Now } \\
\text { Campaign }\end{array}$ & $\begin{array}{l}\text { - What are Millenium Development Goals? } \\
\text { - What do the MDGs number } 4 \text { and } 5 \text { tell us about children's } \\
\text { physical well-being today? } \\
\text { - Introduction on World Vision's Child Health Now campaign }\end{array}$ \\
\hline
\end{tabular}

Note: Adopted from “Education for Global Citizenship," by World Vision, 2016. 
In Sung, Lee and Kim's study (2014) on World Vision's GCED effectiveness, they described how each theme is addressed. During the human rights session, for example, students mainly focus on 'knowledge and understanding' of human rights by reviewing the concept of human rights, Universal Declaration of Human Rights, and history and current states of human rights through lectures, followed by discussions based on few case studies. For the upper secondary students, specific cases such as children soldiers are explored to acknowledge the reality of human rights violation. At the end of session, World Vision's human rights centers are further introduced. Other sessions follow a similar. When discussing environmental issues, students first learn to recognize the seriousness of worldwide clean water scarcity through a series of lectures followed by simulated water activities. For the upper secondary level, students learn about the global food shortage triggered by climate change problems. Through various virtual market games, they learn to understand the reality of countries currently confronting a period of stagflation and political unrest from rising grain prices. Students also discuss about the agonies of agflation to find out the possible ways to prevail the food crisis. Here, World Vision's urgent food support program is introduced. During the Child Health Now session, students design and initiate campaigns to shift the global political and health agenda in order to save the lives of millions of children in needs. In the case of peace session, students watch a movie titled "A Big Miracle," for self-motivation, then learn how to communicate and collaborate with others based on mutual respect. For lower secondary level, students reads the story of Chandra and understand a various perspectives of different characters through role play, thereby learning to develop the values and attitudes of human dignity. In general, World Vision's GCED program attempts employ various learning approaches to promote students' interests in global citizenship activities. Sung, Lee and Kim (2014) note that most classes consist of discussion and other active learning approaches in order to foster commitment to social justice, respect for diversity, solicitude, cooperation, communication ability, problem solving skills. From the descriptions, it is clear that most programs focus on raising awareness in order to combat the immediate sources of suffering in the 'third world' such as poverty, disease, or limited access to education. Nevertheless, they seldom touch on the view of global power imbalances or inequalities. Throughout the program, several centers are introduced as if they are ultimate development 'panacea'; yet, "complex structures, systems, assumptions, power relations and attitudes that create and maintain exploitation and enforced disempowerment and tend to eliminate 
difference" (Andreotti, 2006: 46) are rarely covered. Thus, it can be argued that World Vision presently implements a 'soft' approach in its GCED program.

Other major players in Korea are COPION2) and Good Neighbors. Since 2008, COPION has been providing GCED programs for Korean youth groups to teach global issues, make them to solve the existing problems and to respect diverse cultures and beliefs. Five major programs are currently being operated, namely: (1) COPION Model United Nations, an academic simulation of the United Nations where participants take roles as diplomats to debate and consult about given global agendas and to develop solutions by adopting resolutions, (2) Academy for Global Citizenship, an eight week long lecture series followed by students' presentation and discussion, (3) Global Golden Bell, one day educational event with the form of quiz survival, (4) Global Study Tour, a field visit program conducted abroad for a week to ten days, and (5) COPION University Community, a coalition of university clubs which are interested in international development, voluntary works and global citizenship (COPION, 2016). Similar to the World Vision's case, Academy for Global Citizenship (visiting schools) has become the major program for COPION. Using a participatory learning approach, the program aims to increase public interests in key international issues and to lead active and voluntary actions among citizens for improvement over global problems. The topics include, but not limited to: the issue of globalization, global poverty, environment, human rights, international conflicts, global economy, global citizenship, and so forth. Unlike other big CSO's programs, this program is reported to be largely derived from the Development Education Association and Resources Center (DEAR)3) of Japan.

When carefully reviewing the program, some educational contents appear to keenly reflect critical perspectives as addressed by Andreotti (2006). For instance, a 'fair trade module,' as described in table 5, introduces students how the current vertical trade system can seriously hinder the opportunity for developing countries to enter the market and to compete with the big players who already set the cost at much lower price. Here, coffee is introduced as an example to reflect a material relations of power in the present. Through the simulated experience and activities, students are encourage to struggle through their encounters with others to come to a deeper understanding of global relationality and responsibility.

3) DEAR is a network organization that promotes development education at local and national levels. 
$<$ Table 5> An Sample Lesson Plan for 'What is a good trade: coffee with pleasure' Module

\begin{tabular}{cl}
\hline Module & To understand the realities of coffee product countries and their \\
Objective & - To acknowledge possible challenges during the process of coffee \\
& production and trade and discuss solutions. \\
\hline Estimated Time & - Approximately 4 hours (total) \\
\hline Materials & - Sheet, Cards (included in the textbook) \\
\hline (1) Coffee Q\&A (15-45 mins) \\
- In quiz format \\
- Understand the basic knowledge of coffee plantation and the overall \\
(2) History of Coffee (45 mins) \\
- In card game format \\
- Review the historical moments of coffee trade by reorganizing 8 \\
- different card in chronological order. \\
Understand a long history of domination and exploitation of the \\
Global South by the North. \\
(3) Coffee Plantation (90 minutes) \\
- In simulation activity format \\
- Based on the coffee trade between small coffee farms and big \\
- multinational corps, calculate each part's profit over years. \\
- Understand severe inequality issues during the intransparent process \\
of production and distribution. \\
(4) What's a good trade? (90 minutes) \\
- In group work format \\
and discuss how to improve it.
\end{tabular}

Note: Adopted from "Looking at the World through Participatory Learning" by COPION, 2016.

In the same vein, other modules seem to be comprised of similar 'critical' components. They reflect critical global citizenship by evaluating the responsibility that the North has for creating the conditions that have led to poverty; yet, they do not neglect to include that economical poverty or well-being has no direct correlation to one's human dignity or cultural prosperity (COPION, 2016). What appears to be occurring in COPION's program is that they generally encourage students to work the process differently as they each struggle with their culpability in global relations and with how they may choose to respond through their various positions. In this respect, it can be regarded that COPION offers a relatively well-balanced program that contains both soft and critical perspectives of global citizenship, compared to others.

In Good Neighbors' case, they offer programs, which are quite similar to other 
aforementioned, for learners to understand the lives of those suffering from poverty, disease, war, and to respect their human rights. Two major types of GCED programs have been operated for secondary level students: (1) Me to We, which teaches the importance of sharing and help them respect and cooperate with others, (2) Global Youth Leadership Camp, which helps students understand different global issues and take corresponding community actions. While looking at their programs, both seems to focus on 'soft' approaches to humanitarianism instead of going further into challenging injustice/inequalities and understanding why they come about. For example, Me to We program, which is heavily based on philanthropy education, tends to assume and construct the 'others' to be always in need of the compassionate help of the 'global citizen.' This possibly gives a space to discuss about the model global citizen, as well as typical modes of impassioned global citizenship that are often associated with their humanitarian activities.

$<$ Table 6> Learning Content of Good Neighbor's ME to We Program

\begin{tabular}{cl}
\hline \multicolumn{1}{c}{ Possible Topics } & \multicolumn{1}{c}{ Learning Objectives and Contents } \\
\hline $\begin{array}{c}\text { What does it mean to 'share' } \\
\text { with others? }\end{array}$ & $\begin{array}{l}\text { - Understand what it means to share with others and how } \\
\text { important it is. }\end{array}$ \\
\hline When do we need to share? & - $\begin{array}{l}\text { Learn about the realities of people in need through } \\
\text { watching video clips and discuss why they need help. }\end{array}$ \\
\hline How do we practice sharing? & - Discuss ways to help others. \\
\hline $\begin{array}{c}\text { How one person can help } \\
\text { change the world through } \\
\text { sharing? }\end{array}$ & $\begin{array}{l}\text { Understand how one small individual's effort possibly } \\
\text { can help people suffering from poverty, disaster, } \\
\text { socio-political-cultural oppression around the world. }\end{array}$ \\
\hline
\end{tabular}

Note: Adopted from "Me to We: Philanthropy Education" by Good Neighbors, 2016.

Moreover, based on the analysis of the Good Neighbors' learning contents, it appears that the activity seems to provide a narrow picture of developing countries, which potentially creates stereotypes and simplification of life in the Global South. It also seems that the primary learning goal is for students to recognize their 'privilege' and to regard themselves as 'helpers,' by being empowered. In sum, a 'soft' GCED appears to play an overriding influence in the Good Neighbors' program. 


\section{2) Small/New Programs}

Little research to date has reviewed programs in the context of GCED in smaller or more recent CSOs and thus it is difficult to disentangle which falls into 'soft,' and which programs are 'critical' or even balanced. What appears to be definite about these programs is that a 'one-size fits for all' approach is not an advantage to them and thus they have chosen to create different "nitch" programs based on local's needs to secure their market competitiveness. However, due to the lack of detailed documentations on practices or policies and specifically on country-level implementation, their GCED programs were inevitably practiced based on different "own" assumed criteria that are given from major international organizations. In addition, their parochial approaches can possibly be criticized as a limited learning experiences for seeing a bigger picture to address "complex structures, systems, assumptions, power relations and attitudes that create and maintain exploitation and enforced disembowelment and tend to eliminate difference" (Andreotti, 2006: 46). Just as few major players, the focus of their programs tend to associate with images of global citizen with one who 'helps' and the story of development of humanitarianism becomes the primary source about the helpers. Since they often do not cover its underlying causes, they can be prone to "project and reproduce these ethnocentric and developmentalist mythologies onto the Third World 'subalterns' they are read to help to develop" (Andreotti, 2006: 45). In sum, many program appears to conform to a so-called 'soft' global citizenship approach, which relies on a moral framework for understanding the global interconnectedness and interdependency and understand poverty as a problem that the world has the responsibility to solve.

\section{Conclusion}

The purpose of study was to contribute to the understanding of the current status of GCED programs offered in South Korea using Andreoitti's (2006) framework to provide insights into the current programming practices and status. The study found that most GCED programs are heavily focused on soft approach.

While global citizenship and GCED do not, necessarily, have to be bounded by the form of international development or aid, a large number of CSOs appears to equate global 
citizenship with these categories (Andreotti, 2006; Schattle, 2005) due to their representation in the field. Most programs focus on empowering students to make a difference in others' lives instead of on complex representation of underprivileged people, or global connection and relationships; and this possibly creates a distinction between those who are fortunate and global citizens (helpers) and those who are helped by global citizens (helped). By focusing on the global citizen as helper, global citizenship can be often understood as a moral or ethical identity, as Andreotti (2006) affirms, which one should foster. Such allure of being a helper is quite common in many CSOs' marketing strategies such as their aid sponsorship commercials. Furthermore, it appears that many problems in the Global South is understood as a natural phenomenon that can be solved through technical supports. Many programs seem to unintentionally reinforce the ideas that existing institutions and systems within developing countries are a main cause for problems and lack of development and in that international development or aid can successfully alleviate poverty and other global challenges around the world. However, it is imperative to question the value of aid and development that do not alter the conditions that produce the problems and deprivation or that produce long-standing unbalanced powers between the Global North and South. These programs should also cover the structures and historical decisions that may have produced problems within a global system instead of reflecting global citizenship as the moral obligation between helper and those who need material aid.

There are two possible obstacles that need to be surmounted. First, while the major programs typically offer four to eight week-long programs, most other programs presently require students to participate in one time only event or a week-long program. Thus, the programs can only cover limited topics, for example, introduction to poverty and development. Students are unintentionally exposed to the poverty phenomenon only without appropriate understanding of related causes and structures while impeding opportunities to develop their critical thinking and critical analysis skills. Secondly, as many CSOs regards GCED as a tool to ultimately promote their agenda and activities, they inevidently focus on the question "How should we help?" rather than asking why they live in such circumstances. The former question generally leads to the point where donation and aid are needed while the latter seeks to understand the causes of inequality. Asking 'why' people live in poverty can possibly lead to help and also empower other forms of action towards change. This can help students to recognize their own positions within a global system, as what Andreotti 
(2006) calls a 'critical' approach to global citizenship.

It is important to note that the study is not to argue that 'soft' approach to GCED is inadequate or false. 'Soft' GCED may appear to be shallow; yet, it still presents a starting point for involvement with global issues. However, as CSOs in Korea presently play a key role in providing GCED at the national level, a more balanced approach that contains 'critical' elements of global citizenship is in demand to create meaningful changes that have a long term effect. If not, they may soon face a serious danger of engaging in and promoting a 'sunny-side' of global citizenship that perpetuate voluntarism, charity-based and neocolonial approaches to the issues of global social and environmental injustice. For this, a more complex web of cultural and material contexts should be examined and analyzed in order to reveal the cause and effect of global problems and to foster appropriate actions. For instance, students can be asked to research particular subjects and provide an analysis of the complex relationship that produce poverty and disaster. Such can include research the structural causes for inequality or injustice, material relationship with others, or even the myriad of social movements around the world. Some may argue that students' levels or ages can limit their abilities to develop and engage in complex critical thinking and problem solving. However, Oxfam (2006) suggests, as noted earlier, that such is not necessarily required at the foundational level, but can be implemented as students' knowledge, skills and attitude advance.

It is important to keep in mind several limitations of the study. First, the study was done under a severe time constraint and hence all the relevant issues could not be precisely put to detailed scrutiny. Analysis of programs over a period time would have given better picture of CSOs' GCED practices. Secondly, due to the limited access and availability of resources, only three major programs could be examined in details while others are briefly reviewed. This is largely because GCED in South Korea is still considered to be in nascent stages except these major programs and therefore the future research needs to further include personal or group interviews to better understand the perspectives of different programs. This study nevertheless provides a snapshot of the GCED programs offered by local CSOs in South Korea as well the potential usefulness of Andreotti's (2006) analytical framework. 
References

Andreotti, V. (2006). Soft versus critical global citizenship education. A Development Education Review, 3, 40-51.

Blackmore, C. (2014). The Opportunities and Challenges for a Critical Global Citizenship Education in One English Secondary School. Doctoral dissertation, University of Bath.

Chung, B. (2014, December). Global citizenship education (GCED) and curriculum governance in Korea. Norrag News. Retrieved from http://www.norrag.org/en/publications/norrag-news/ online-version/education-and-skills-post-2015-and-the-global-governance-of-educatio n-agendas-and-architecture/detail/global-citizenship-education-gced-and-curriculumgovernance-in-korea.html.

COPION. (2016). Copion planetary global citizenship school. Seoul, Korea.

Davies, I., Evans, M. \& Reid, A. (2005). Globlising citizenship education? A critique of 'global education' and 'citizenship education'. British Journal of Educational Studies. 32(2), 183-194.

Dobson, A. (2005). Globalisation, cosmopolitanism and the environment. International Relations, 19, 259-273.

Dobson, A (2006) Thick cosmopolitanism, Political Studies, 54, 165-184.

Education Above All (2012). Education for global citizenship. Doha, Qatar: John Gregg.

Falk, R. (1994). The making of global citizenship. In B. Vansteenbergen, (Ed). The Condition of Citizenship. Londor. The Sage Publications.

Gadsby, H., \& Bullivant, A. (Eds.). (2011). Global learning and sustainable development. New York, NY: Taylor \& Francis.

Good Neighbors (2016). Me to We workbook for secondary school students. Seoul, Korea. Han. J., Lee. K., \& Shin. J. (2012) The status of educational work in the Korean development NGO. International Development and Cooperation Review, 2(2), 127-172.

Kim, C., \& Sim, H. (2015) Global citizenship education online information session reading material. Retrive from:

http:/ / plus.google.com/u/0/communities/11548589210244810632/stream/ca9298d57182-49d1-aa69-8b03ff402092.

Kim, J., Cha, Y., Pak, S., \& Lee, J. (2014). Global citizenship education for peace and cooperation: 
Research agenda formulation for the 2015 world education forum Seoul, Korea: Korean National Commission for UNESCO.

Korea Civil Society Forum on International Devleopment Cooperation (2015). Trends and direction of CSO's educational development and cooperation Seoul, Korea: Ministry of Education. Korea NGO Council for Overseas Development Cooperation (2014). CSO index for international development cooperation. Seoul, Korea.

Langdon, J., \& Agyeyomah, C. (2014). Critical hyper-reflexivity and challenging power: Pushing past the dichotomy of employability and good global citizenship in development studies experiential learning contexts. In R. Tiessen \& R. Huish. (Eds.), Globetrotting or Global Citizenship: Perils and Potential of International Experiential Learning (pp. 43-70). Toronto: University of Toronto Press.

Lee, T. (2009). International development education for fostering global citizenship: From primary to upper secondary school students. Seoul, Korea.

Leslie, A. (2009). Sustainable communities: The role of global citizenship education. The Journal of the Society For Greek Political Thought, 2(Winter), 1-44.

Martin, F. (2008). Mutual learning: The impact of a study visit course on teachers' knowledge and understanding of global partnerships. Critical Literacy: Theories and Practices, 2 (1), 60-75.

Massey, K. (2014). Global Citizenship Education in a Secondary Geography Course: The Students' Perspectives. Review of International Geographical Education Online, 4(2), 80-101.

Ministry of Foreign Affairs. (2013). Outcomes of the technical consultation on global citizenship. [Press release]. Retreived from http://www.mofa.go.kr/ENG/press/pressreleases/index. jsp?menu=m_10_20\&sp=/webmodule/htsboard $/$ template $/ \mathrm{read} /$ engreadboard.jsp $\% 3$ Fboardid=302\%26typeID=12\%26tableName=TYPE_English $\% 26$ seqno=312751

Noddings, N. (2005). Educating citizens for global awareness. NY: Teachers College Press. O'Sullivan, M., \& Pashby, K. (Eds.). (2008). Citizenship education in the are of globalization: Canadian perspectives. Rotterdam, The Netherlands: Sense Publication.

Oxfam (1997). A curriculum for global citizenship. Oxford: Oxfam Great Britain. Oxfam (2006). Education for global citizenship. A guide for schools. Oxford: Oxfam Great Britain. Pak, S. (2013). Global citizenship education. Seoul, Korea: APCEIU Research Report.

Pashby, K. (2011). Cultivating global citizens: Planting new seeds or pruning the perennials? Looking for the citizen-subject in global citizenship education theory. Globalisation, Societies and Education, 9(3), 427-442. 
Schattle, H. (2005). Communicating global citizenship: Multiple discourses beyond the academy. Citizenship Studies, 9(2), 119-133.

Schattle, H. (2008). Education for global citizenship: Illustrations of ideological pluralism and adaptation. Journal of Political Ideologies, 13(1), 73-94.

Sim, H. (2015). Learning to change: Program evaluation of global citizenship education in South Korea (Unpublished doctoral dissertation). Seoul National University, Korea.

Standish, A. (2008). Global perspectives in the geography curriculum Reviewing the moral case for geography. London: Routledge.

Spivak, G. (1990). The post-colonial critic: Interviews, strategies, dialogues, NY: Routledge.

Spivak, G. (2003). A conversation with Gayatri Chakravorty Spivak: Politics and the imagination, interview by J Sharpe, Signs: Journal of Women in Culture and Society, 28, 609-624.

Spivak, G. (2004) Righting wrongs, The South Atlantic Quarterly, 103, 523-581.

Sung, Y., Lee. H., \& Kim. M. (2014). Evaluation study of World Vision's global citizenship education program Seoul, Korea: Kyung Hee University.

Tarc, P. (2011). How does 'global citizenship education' construct its present? The crisis of international education. In V. Andreotti \& L.M. de Souza (Eds.), Postcolonial Perspectives on global citizenship education, London: 105-123.

UNESCO. (2013). Global citizenship education: An emerging perspectives. Outcome document of the technical consultation on global citizenship education (Report No. ED/2013/PSD/PHR/PI/4). Paris, France.

UNESCO APCEIU (2013). GCE in every corners of the world: Four tales, one goal to foster global citizenship education. Sangseng, 37, 23-24.

World Vision. (2016) World Vision's global citizenship education. Seoul, Korea.

YMCA Korea (2012). Reports on visiting planetary citizenship education program for children and youth Seoul, Korea.

* Received January 1, 2016 / Revised March 20, 2016 / Accepted April 30, 2016

* Dr. Heelung Raina Sim received her Bachelor of Arts in economics from Emory University and Master' s degree in intemational and transcultural studies (with a concentration bilingual and bicultural education) from Teachers College, Columbia University. She obtained her PhD. degree in global education cooperation (intemational educational development) from the Seoul National University. She is cumently a postdoctoral research fellow at the Asia Development Institute of Seoul National University.

*E-mail: rainasim@snu.ac.kr 